\title{
Diversity of Diptera species associated with pig carcasses in a Brazilian city exposed to high rates of homicide
}

\author{
Tadeu Morais Cruz ${ }^{1,2}$; Taciano Moura Barbosa ${ }^{2,4,5}$; Patrícia Jacqueline Thyssen ${ }^{3}$ \& Simão Dias Vasconcelos ${ }^{2,6}$
}

1 Governo do Estado de Pernambuco, Secretaria de Defesa Social. Recife, PE, Brasil. ORCID: http://orcid.org/0000-0003-2436-7053. E-mail: tadeumcruz@yahoo.com.br

2 Universidade Federal de Pernambuco (UFPE), Centro de Biociências (CB), Departamento de Zoologia, Laboratório de Insetos de Importância Forense. Recife, PE, Brasil.

${ }^{3}$ Universidade Estadual de Campinas (UNICAMP), Instituto de Biologia (IB), Departamento de Biologia Animal, Laboratório de Entomologia Integrativa (LEI). Campinas, SP, Brasil. ORCID: http://orcid.org/0000-0001-7343-2419. E-mail: thyssenpj@yahoo.com.br

${ }^{4}$ Universidade Federal do Rio Grande do Norte (UFRN), Centro de Biociências (CB), Departamento de Microbiologia e Parasitologia (DMP) , Laboratório de Insetos e Vetores (LIVE). Natal, RN, Brasil (current address).

${ }^{5}$ ORCID: http://orcid.org/0000-0002-5495-258X. E-mail: tacianomoura7@gmail.com

${ }^{6}$ ORCID: http://orcid.org/0000-0002-8722-0836. E-mail: simao.vasconcelosfo@ufpe.br

\begin{abstract}
Cities in northeastern Brazil experience extreme rates of unsolved homicides, a situation that stimulates innovative procedures in the police work, such as forensic entomology. We surveyed necrophagous insects associated with carrion in a city exposed to high rates of homicides in Northeastern Brazil. The experiments were carried out in a rainforest fragment located in Recife, State of Pernambuco. Two pig carcasses were used as models, one in the dry and the other in the rainy season. The collection of adults was performed daily until the complete skeletonization of the carcasses. At least 32 Diptera species from the families Calliphoridae, Muscidae, Sarcophagidae, Fanniidae, Phoridae, Anthomyiidae, Piophilidae, and Stratiomyidae were registered, some of which have been previously documented on cadavers. A high richness of Diptera species was registered in all stages of decomposition. A strong overlap in the occurrence of most species was observed, which invalidates a defined entomological succession on the carcasses. Two species stood out in terms of abundance: Ophyra chalcogaster (Muscidae) and Chrysomya albiceps (Calliphoridae). The ubiquity of Hemilucilia semidiaphana (Calliphoridae) seems to confirm its preference for forest fragments exposed to low anthropogenic action. Our data contribute to expand the knowledge on the geographical distribution of forensically relevant species in the region and confirm the rapid dissemination of invasive Chrysomya species in forested areas.
\end{abstract}

Key-Words. Calliphoridae; Chrysomya; Forensic entomology; Muscidae, Ophyra.

\section{INTRODUCTION}

Few areas in the world are as appropriate to develop forensic entomology as Northeastern Brazil. Depending on the criminality indices considered, 12 out of the 50 most violent big cities in the world (in countries not experiencing war) are located in that region (Mexico, 2017). Nevertheless, forensic entomology's local development is hampered by the scarcity of research on the diversity and life cycle of necrophagous species. So far, 14 insect species from five Diptera families (Calliphoridae, Sarcophagidae, Fanniidae, Muscidae, and Phoridae) have been recorded from human cadavers in the region (Andrade et al., 2005; Oliveira \& Vasconcelos, 2010; Vasconcelos et al., 2014, 2019), a figure that is overly underestimated.
Species of Diptera from at least 11 families are known to colonize human corpses at different decomposition stages (Byrd \& Castner, 2010). Some of them have been demonstrated to locate carrion a few minutes after the death (Vasconcelos et al., 2013). Bionomical data on blow fly species (Calliphoridae) have been used to determine the minimum post-mortem interval (minPMI) in several countries (Arnaldos et al., 2001; Kosmann et al., 2011), and it is expected that a growing body of quantitative data will help to expand this utility in South America.

Since the geographical region where a corpse is found affects not only the structure of the necrophagous community but also the temporal pattern of colonization, entomological evidence obtained in one area cannot always be extrapolated 
to estimate the minPMI in a different region (Tomberlin et al., 2012). Checklists of necrophagous species in distinct environments can be useful to determine if there was post-mortem transfer of the corpse or, under a conservationist approach, to assess the potential of some species as biological indicators of anthropogenic action (Cabrini et al., 2013; Carmo \& Vasconcelos, 2016, Barbosa et al., 2017). Variations in the structure and composition of insect assemblages throughout the year also help in associating the likelihood of cadaver colonization by insects to a particular season, as evidenced in Argentina (Horenstein et al., 2012), Brazil (Carvalho \& Linhares, 2001), and Japan (Tachibana \& Numata, 2006).

We investigated the diversity of forensically relevant Diptera species in a peri-urban fragment of rainforest located in Recife, capital of the State of Pernambuco, which has a shocking homicide rate of 33/100,000 inhabitants (Waiselfisz, 2016). Specifically, we aimed to: (a) survey necrophagous species of Diptera associated with carrion using pig carcasses as models; (b) relate the occurrence of species to the stage of carcass decomposition; (c) detect the occurrence of invasive species in the environment; and (d) identify species with potential use for forensic entomology in the region.

\section{MATERIAL AND METHODS}

The field study took place in Dois Irmãos State Park, a 388-ha preserved rainforest fragment located in
Recife $\left(08^{\circ} 07^{\prime} 30^{\prime \prime} \mathrm{S}, 34^{\circ} 52^{\prime} 30^{\prime \prime} \mathrm{W}\right.$, altitude $\left.40 \mathrm{~m}\right)$ (Fig. 1A). The local climate is hot and humid, with mean rainfall ca. 2,500 $\mathrm{mm} /$ year, the average annual temperature ca. $25.6^{\circ} \mathrm{C}$, and two well defined seasons: dry (OctoberFebruary) and rainy (March-September). Vegetation is classified as dense ombrophylous forest, with sparse clearings (Machado et al., 1998). The area was chosen due to its proximity to urban settings (ca. $2 \mathrm{~km}$ ) and because it is similar to common repositories used for clandestine dumping of cadavers resulting from homicides.

As a model, we used pigs (Sus scrofa, ca. $15 \mathrm{~kg}$ ), which were killed in loco with a gunshot to the occipital region, a procedure authorized by the Research Ethics Committee of the Federal University of Pernambuco (protocol No. 23076.030693/2009-23). After the death, the carcass was immediately placed in a metal cage $(0.9 \mathrm{~m} \times 0.6 \mathrm{~m} \times 0.5 \mathrm{~m})$ to prevent disturbance by large scavengers (Fig. 1B). Around the cage, a Shannon's inverted trap (Fig. 1B), made up of a metal frame (2 $\mathrm{m}$ hig $\mathrm{h} \times 1 \mathrm{~m}$ long $\times 1 \mathrm{~m}$ wide) covered with a fine white mesh fabric, was placed to trap insects that visited the carcass. A $30 \mathrm{~cm}$ gap between the bottom of the net and the soil was left, through which insects could access the carcass.

To maximize the collection of insects from different species and respecting the legal and ethical restraints imposed by local committee rules, two pigs were sacrificed; one in the dry season (January) and the other in the rainy season (July). Sampling took place at every $24 \mathrm{~h}$ until the $11^{\text {th }}$ day, and at every $48 \mathrm{~h}$ after that until complete skeletonization of the carcass. The decomposition

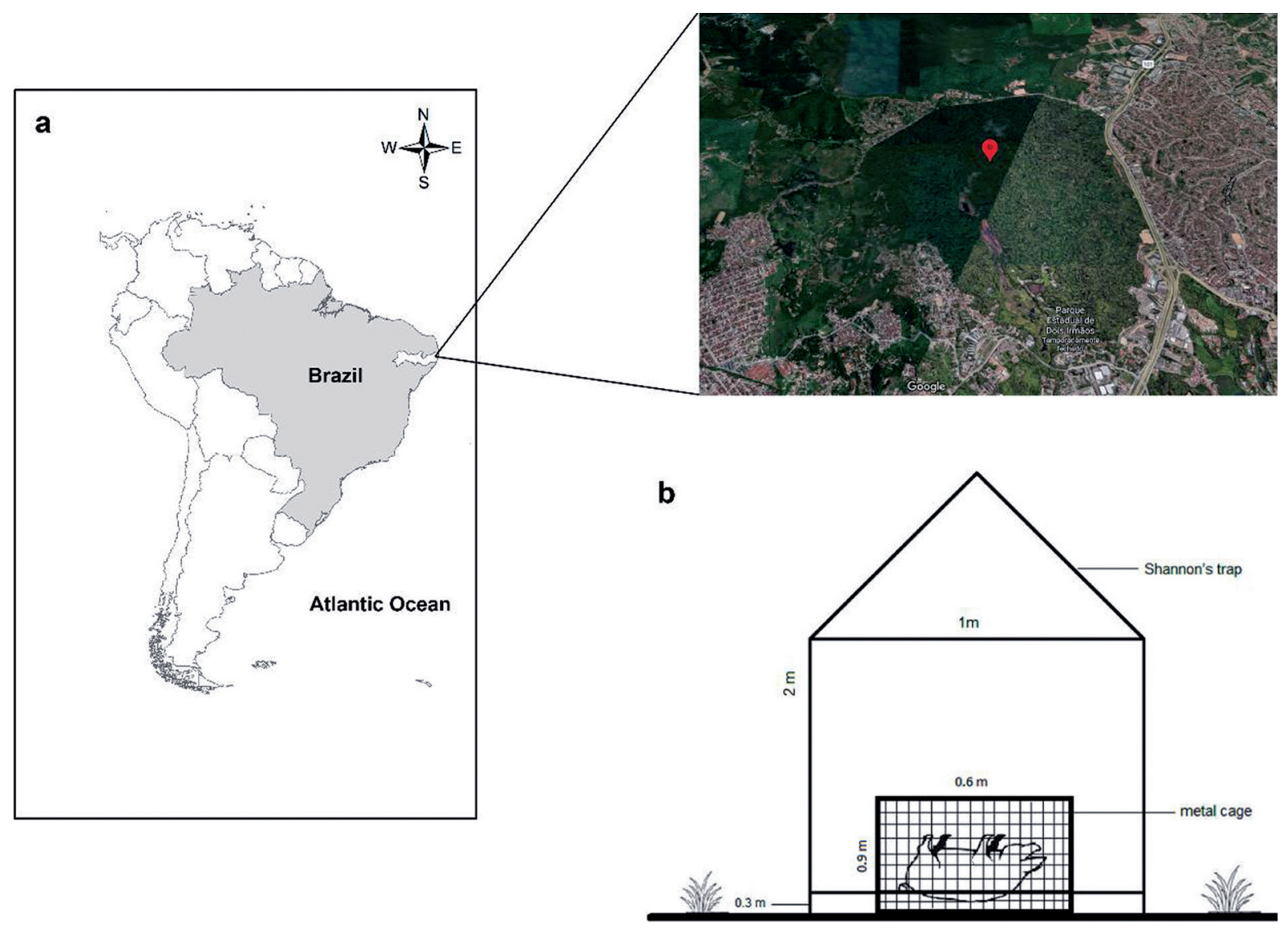

Figure 1. (A) Location of sample sites in the Dois Irmãos State Park in Recife and (B) structure used in the attraction and collection of insects. 
stages were classified according to Rodriguez \& Bass (1983). Flies trapped in the mesh structure were collected by sweeping an entomological net $(20 \mathrm{~cm}$ diameter) for 20 minutes on each sampling day, always between 12:00h and 14:00h. Insects were killed using ethyl acetate and identified using taxonomical keys (Mc Alpine et al., 1981; Carvalho et al., 2002; Carvalho \& Mello-Patiu, 2008; Disney \& Aguiar, 2008; Rochefort et al., 2015). All specimens were deposited in the Entomological Collection at the Federal University of Pernambuco, Brazil (Curator: L. Iannuzzi). Data on the overall stage of decomposition, presence of insects, and abiotic factors - temperature, relative humidity, weather conditions, and rainfall - were collected in loco every day sampled.

The composition and the structure of the assemblages were examined under the following variables: richness, abundance, diversity, dominance, and evenness, all of which were refined per season and stage of decomposition. A Chi-square test was used to analyze the difference in the richness between seasons and stages. We estimated Shannon-Weiner's diversity $\left(\mathrm{H}^{\prime}\right)$, Pielou's evenness (J), and Simpson's dominance (D) for each stage of decomposition in both seasons. We built a ranking of species' dominance in each season using a logarithmic transformation of the abundance of all species. The assemblage of dipterans was analyzed in terms of structure (abundance) and composition (presence/absence) using ordination analysis constructed through the Bray Curtis matrix. To evaluate the similarity among the decomposition stages, a grouping analysis was performed to visualize graphical differences. All ecological and statistical analyses were carried out using Primer $^{\circledR}$ 6.0, BioEstat ${ }^{\circledR}$ 5.3, and SigmaPlot with a significance level of $5 \%$.

\section{RESULTS}

Throughout the experiment, mean diurnal temperature varied from $29.6^{\circ} \mathrm{C}\left(\min =28.1^{\circ} \mathrm{C}\right.$, $\left.\max =30.9^{\circ} \mathrm{C}\right)$ in the dry to $25.4^{\circ} \mathrm{C}\left(\min =23.5^{\circ} \mathrm{C}, \max =26.9^{\circ} \mathrm{C}\right)$ in the rainy season. Overall weather conditions were sunny in the dry season, with only two cloudy days during the entire decomposition period. In the rainy season, on the other hand, sunny days were sporadic; rainy and/ or cloudy days corresponded to 25 of the 30 days of the experiment. Relative humidity varied from $61 \%$ to $73 \%$ (mean $=66.7 \%$ ) in the dry and from $71 \%$ to $93 \%$ (mean $=81.2 \%$ ) in the rainy season. Accumulated rainfall during the experiment was $25 \mathrm{~mm}$ in the dry and $230 \mathrm{~mm}$ in the rainy season.

Decomposition of both carcasses occurred fast, and only four phases of decomposition were discernible: fresh, bloated, decay, and dry (Tables 1 and 2). The fresh stage lasted 24 hours in the dry season and 72 hours in the rainy season; the bloated stage and the decay stage lasted 48 hours each in both experiments. After 25 days (dry season) and 30 days (rainy), there were not soft tissues left in the carcass, and adult dipterans were virtually absent.

When the numbers of individuals from the two experiments were added, a total of 10,410 insects be- longing to 19 families were registered. Of these, 10,116 belonged to eight families whose species exhibit an association with decomposing carcasses: Calliphoridae, Sarcophagidae, Muscidae, Fanniidae, Piophilidae, Mesembrinellidae, Anthomyiidae, Phoridae, and Stratiomyidae (Tables 1 and 2). Species from the families Neriidae, Tabanidae, Asilidae, Milichiidae, Drosophilidae, Micropezidae, Dixidae, and Ropalomeridae were also collected in small amounts in both seasons. Because of their limited abundance (individuals from these eight families summed up $3.7 \%$ of total) and the debatable nature of their necrophagy, they were not considered for this study.

The families with the highest number of species were Calliphoridae (7 species) and Muscidae (5) (Tables 1 and 2). Fanniidae and Piophilidae were represented by four and three species, respectively. Due to the absolute prevalence (>90\%) offemales in the samples and difficulties in identifying, specimens from Sarcophagidae were treated as a single taxon. Whenever possible, sarcophagids were identified to a specific level, and at least 10 species were registered: Blaesoxipha (Gigantotheca) plinthopyga Wiedemann, 1830; Oxysarcodexia modesta Lopes, 1946; Oxysarcodexia fluminensis Lopes, 1946; Oxysarcodexia riograndensis Lopes, 1946; Oxysarcodexia intona Curran \& Walley, 1934; Oxysarcodexia avuncula Lopes, 1933; Oxysarcodexia sp.; Peckia (Squamatodes) ingens Walker, 1849; Oxyvinia excisa Lopes, 1950 and Tricharaea (Sarcophagula) sp.

Two families stood out in the experiment performed during the dry season, Calliphoridae and Sarcophagidae, as their combined abundances represented over $80 \%$ of all specimens. Muscidae (61.2\% of all adults) and Calliphoridae (22.8\%) were the most abundant families in the rainy season. Two species had the highest abundances: Ophyra chalcogaster (Wiedemann, 1824) (Muscidae), particularly in the rainy season (59.5\% of all adults), and Chrysomya albiceps (Wiedemann, 1819) (Calliphoridae) in the dry season (38.4\%). Codominance occurred between two invasive blow fly species, C. albiceps and Chrysomya megacephala (Fabricius, 1794) in the dry season, while O. chalcogaster (Muscidae) and Hemilucilia semidiaphana (Rondani, 1850) were codominant in the rainy season (Fig. 2).

High diversity of necrophagous species of Diptera was associated with the carcasses throughout the entire decomposition (Tables 1 and 2). The number of carrion-associated species did not seem to differ markedly throughout the decomposition $\left(X^{2}=1.156\right.$; d.f. $=3$; $P>0.05)$. For example, when data from the two carcasses were combined, 21 species were reported at the fresh stage; 20 at the bloated stage, 15 at the decay stage, and 20 at the dry stage.

There was no difference in the richness of species between the stages of decomposition in the dry stage $\left(X^{2}=2.342 ;\right.$ d.f. $\left.=3 ; P=0.504\right)$, but the fresh and the dry stages harbored a significantly higher number of species in the rainy season $\left(X^{2}=11.043\right.$; d.f. $\left.=3 ; P<0.05\right)$. Overall abundance also varied between the stages in both dry $\left(X^{2}=1,582 ;\right.$ d.f. $\left.=3 ; P<0.001\right)$ and rainy seasons $\left(X^{2}=5,480 ;\right.$ d.f. $\left.=3 ; P<0.001\right)$. The highest relative fre- 
Table 1. Diversity and abundance of Diptera associated with a pig carcass in the dry season in a forest fragment in Pernambuco State, Brazil.

\begin{tabular}{|c|c|c|c|c|c|c|}
\hline Family & Species & Fresh & Bloated & Decay & Dry & Total \\
\hline \multirow[t]{7}{*}{ Calliphoridae } & Chrysomya megacephala (Fabricius, 1794) & 81 & 268 & 12 & 23 & 384 \\
\hline & Chrysomya albiceps (Wiedemann, 1819) & 415 & 1045 & 46 & 160 & 1,666 \\
\hline & Chrysomya putoria (Wiedemann, 1818) & 10 & 16 & - & 9 & 35 \\
\hline & Hemilucilia semidiaphana (Rondani, 1850) & 23 & 13 & 9 & 44 & 89 \\
\hline & Hemilucilia segmentaria (Fabricius, 1805) & 14 & 4 & 4 & 30 & 52 \\
\hline & Cochliomyia macellaria (Fabricius, 1775) & - & 2 & - & 1 & 3 \\
\hline & Lucilia eximia (Wiedemann, 1819) & 1 & - & - & - & 1 \\
\hline Mesembrinellidae & Mesembrinella bellardiana Aldrich, 1922 & 6 & 4 & 9 & 25 & 44 \\
\hline \multirow[t]{5}{*}{ Muscidae } & Parapyrellia maculipennis (Macquart, 1846) & 11 & 40 & 17 & 13 & 81 \\
\hline & Morelia humeralis (Stein, 1918) & 6 & 52 & 18 & 14 & 90 \\
\hline & Musca domestica Linnaeus, 1758 & 1 & 2 & - & 1 & 4 \\
\hline & Biopyrellia pipuncta (Wiedemann, 1830) & - & 3 & 5 & 1 & 9 \\
\hline & Ophyra chalcogaster (Wiedemann, 1824) & 6 & 29 & 11 & 19 & 65 \\
\hline \multirow[t]{2}{*}{ Fanniidae } & Fannia obscurinervis (Stein, 1900) & 1 & - & - & - & 1 \\
\hline & Fannia sp.1 & 一 & 一 & 1 & - & 1 \\
\hline \multirow[t]{3}{*}{ Piophilidae } & Dasyphlebomyia stylata Becker, 1914 & - & 2 & - & 3 & 5 \\
\hline & Piophila bipunctata (Fallen, 1810) & - & 1 & - & 1 & 2 \\
\hline & Piophila casei (Linnaeus, 1758) & 一 & 3 & 7 & 16 & 26 \\
\hline \multirow[t]{2}{*}{ Phoridae } & Megaselia scalaris (Loew, 1866) & - & 7 & 5 & 10 & 22 \\
\hline & Phoridae spp. & - & 1 & - & 5 & 6 \\
\hline Stratiomyidae & Hermetia illucens (Linnaeus, 1758) & 一 & 1 & 3 & 23 & 27 \\
\hline$\underline{\text { Sarcophagidae }}$ & Unidentified species & 192 & 734 & 605 & 213 & 1,744 \\
\hline Total & & 767 & 2,227 & 752 & 611 & 4,357 \\
\hline
\end{tabular}

Table 2. Diversity and abundance of Diptera associated with a pig carcass in the rainy season in a forest fragment in the State of Pernambuco, Brazil.

\begin{tabular}{|c|c|c|c|c|c|c|}
\hline Family & Species & Fresh & Bloated & Decay & Dry & Total \\
\hline \multirow[t]{4}{*}{ Calliphoridae } & Chrysomya megacephala & 95 & 89 & 2 & 9 & 195 \\
\hline & Chrysomya albiceps & 164 & 101 & 7 & 20 & 292 \\
\hline & Chrysomya putoria & 8 & 4 & - & 3 & 15 \\
\hline & Hemilucilia semidiaphana & 293 & 145 & 36 & 74 & 548 \\
\hline \multirow[t]{4}{*}{ Mesembrinellidae } & Hemilucilia segmentaria & 23 & 15 & 7 & 3 & 48 \\
\hline & Cochliomyia macellaria & - & - & - & 1 & 1 \\
\hline & Lucilia eximia & - & - & - & 1 & 1 \\
\hline & Mesembrinella bellardiana & 54 & 146 & 9 & 68 & 277 \\
\hline \multirow[t]{4}{*}{ Muscidae } & Parapyrellia maculipennis & 4 & 12 & 20 & 23 & 59 \\
\hline & Morelia humeralis & 2 & 4 & 8 & 31 & 45 \\
\hline & Musca domestica & 1 & - & - & 1 & 2 \\
\hline & Ophyra chalcogaster & 540 & 2,977 & 30 & 43 & 3,590 \\
\hline \multirow[t]{3}{*}{ Anthomyiidae } & Craspedochoeta punctipennis & 8 & - & - & - & 8 \\
\hline & Hylemyiode plurinervis & 2 & - & - & - & 2 \\
\hline & Hylemyiode aureficies & 1 & - & - & - & 1 \\
\hline \multirow[t]{4}{*}{ Fanniidae } & Fannia obscurinervis & 4 & - & - & - & 4 \\
\hline & Fannia sp.1 & 6 & - & - & - & 6 \\
\hline & Fannia sp.2 & 6 & 1 & - & - & 7 \\
\hline & Fannia sp.3 & 6 & - & - & - & 6 \\
\hline \multirow[t]{3}{*}{ Piophilidae } & Dasyphlebomyia stylata & 23 & 9 & 3 & 2 & 37 \\
\hline & Piophila bipunctata & 7 & 2 & 1 & - & 10 \\
\hline & Piophila casei & 41 & 55 & 2 & 21 & 119 \\
\hline \multirow[t]{2}{*}{ Phoridae } & Megaselia scalaris & 55 & 63 & 15 & 16 & 149 \\
\hline & Phoridae spp. & 20 & 8 & - & 6 & 34 \\
\hline Stratiomyidae & Hermetiaillucens & 1 & 3 & 3 & 16 & 23 \\
\hline Sarcophagidae & Unidentified species & 21 & 93 & 74 & 92 & 280 \\
\hline Total & & 1,385 & 3,727 & 217 & 430 & 5,759 \\
\hline
\end{tabular}

quency of necrophagous insects occurred at the bloated stage $(51 \%$ of all specimens in the dry and $64 \%$ in the rainy season).

The highest values of diversity and evenness were registered in the dry stage for both rainy $\left(\mathrm{H}^{\prime}=2.657\right.$; $\left.\mathrm{J}^{\prime}=0.815\right)$ and dry seasons $\left(H^{\prime}=2.244 ; J^{\prime}=0.842\right)$, although these indices varied little across the stages (Table 3). The similarity of the assemblages across decomposition stages was as follows: in the dry season, two major groups were formed: one related to the fresh stage and the other comprising bloated, decay, and dry, with practically $100 \%$ of the species co-occurring in the bloated and dry 


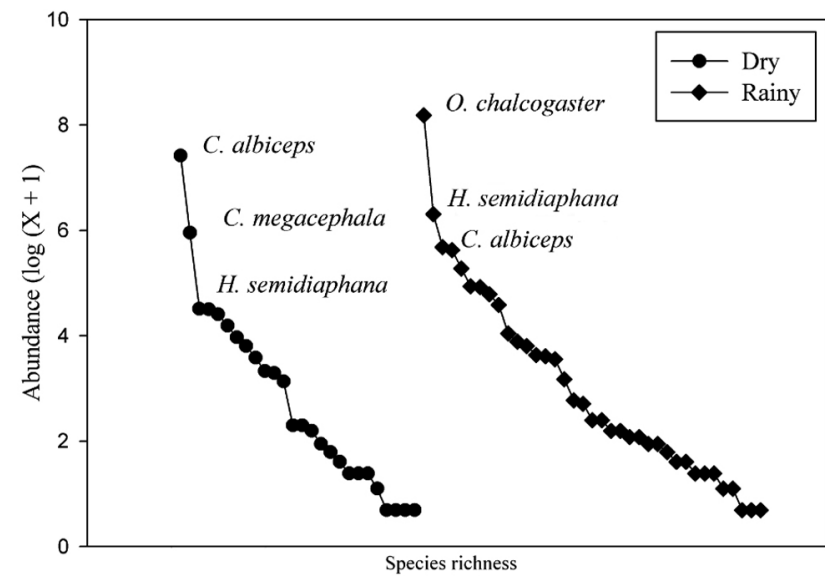

Figure 2. Dominance ranking for dipterans species according to the season (Dry or Rainy).

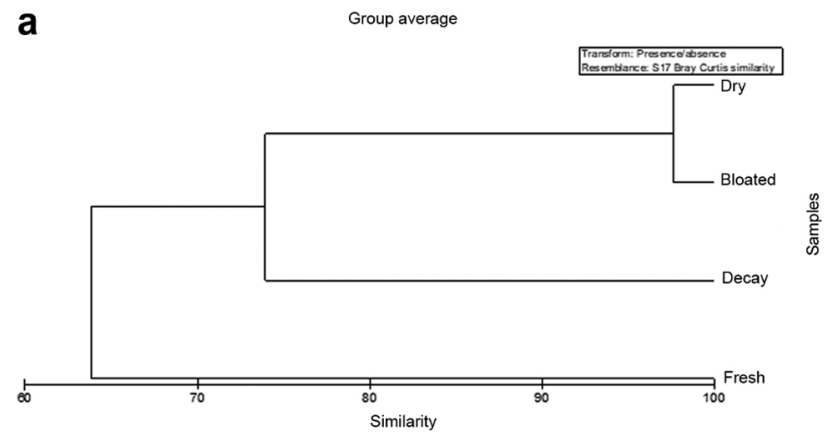

b

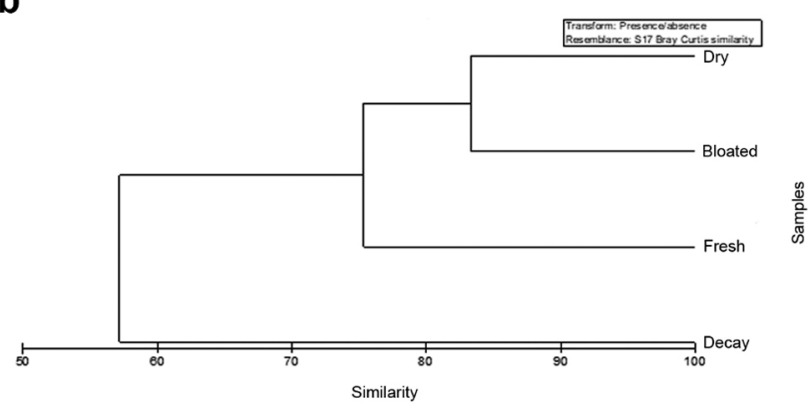

Figure 3. Similarity analysis (Clusters dendrogram) of the diversity of necrophagous Diptera species between decomposition stages: (A) in the season dry and (B) season rainy.

stages (Fig. 3A). In the rainy season, assemblages in the bloated and dry stages were also highly similar, but a separate group formed by insects in the fresh, bloated, and dry stages (Fig. 3B).

\section{DISCUSSION}

Abiotic conditions, that is, high temperature and humidity (and intense rainfall in the rainy season), resulted in fast decomposition of the carcasses, a pattern that was found in other studies performed in the Neotropical region (Carvalho \& Linhares, 2001; Souza \& Linhares, 1997). However, the extremely short duration of the decay phase - two days in both carcasses - was more drastic than what was observed in studies performed in other rainforest fragments in South America (Moura et al., 2005; Barbosa et al., 2010). This phenomenon is associ-
Table 3. Ecological indices of assemblages of necrophagous Diptera according to the decomposition stage; $S=$ richness of species, $N=$ abundance, $J^{\prime}=$ equity, $H^{\prime}=$ Shannon's diversity; $D=$ Simpson's dominance.

\begin{tabular}{cccccc}
\hline Season/Stage & $\mathbf{S}$ & $\mathbf{N}$ & $\mathbf{J}^{\prime}$ & $\mathbf{H}^{\prime}$ & $\mathbf{D}$ \\
\hline Dry & & & & & \\
Fresh & 12 & 767 & 0.404 & 1.094 & 0.464 \\
Bloated & 17 & 2,227 & 0.3522 & 1.089 & 0.480 \\
Decay & 13 & 752 & 0.7369 & 2.28 & 0.860 \\
Dry & 17 & 611 & 0.8421 & 2.244 & 0.819 \\
\hline Rainy & & & & & \\
Fresh & 22 & 1,385 & 0.5877 & 2.055 & 0.779 \\
Bloated & 15 & 3,727 & 0.308 & 0.9521 & 0.351 \\
Decay & 13 & 217 & 0.7496 & 1.797 & 0.788 \\
Dry & 16 & 430 & 0.8155 & 2.657 & 0.912 \\
\hline
\end{tabular}

ated with behavioral and physiological traits in necrophagous dipterans that ensure the immediate location and colonization of an ephemeral resource (Hanski, 1987).

The numerical dominance of species of Calliphoridae and Sarcophagidae observed here derives from their intimate association with decomposing carrion as a site for egg and/or larvae laying and the development of immature stages (Carvalho et al., 2012). The dominance of a few blow fly species, such as C. albiceps, C. megacephala, and Hemilucilia semidiaphana Rondani, 1850 is not surprising since these species are frequently associated with carrion to which they are attracted by decomposing tissues and blood (Vasconcelos et al., 2013). Furthermore, Chrysomya species may cause deleterious effects on the population of native Calliphoridae, such as Cochliomyia macellaria (Fabricius, 1775) (Faria et al., 1999). However, the numerical dominance of the muscid species $O$. chalcogaster had not been described in previous studies in South America. Larvae of Ophyra species can occur in extremely diverse habitats, including dung, putrefied meat, and even decomposing vegetal matter, and they are also reported to prey upon larvae of Sarcophagidae, Calliphoridae, and Muscidae species (Skidmore, 1985; Pamplona \& Couri, 1989; Krüger et al., 2004).

The high richness and abundance of dipterans reported in all stages of decomposition are typical of $r$-strategist species. Although no difference in richness was observed among the stages, the highest proportion of insects was observed in the bloated stage, which is noticeable considering that this phase only lasted 48 hours, compared to a much longer dry stage duration. Females tend to concentrate their oviposition activity at initial stages due to a preference for soft tissues. In the dry (or remains) stage, there can be a radical reduction in the tissues, muscles, and viscera suitable for larval feeding (Payne, 1965).

The ephemeral nature of the carcass requires an efficient location mechanism by adult females - for instance, $H$. semidiaphana can locate an animal carcass within 30 minutes of the death, a fact the gives them an advantage over other species (Vasconcelos et al., 2013). Contrarily to reports that associate Hermetia illucens Linnaeus, 1758 solely to advanced stages of decomposition (Ferrari et al., 2009), the species was registered since the first day 
post-death and continued to be collected throughout decomposition.

Assemblages of necrophagous insects are modeled by processes such as intra- and interspecific competition, predation, and even cannibalism (Wells \& Greenberg, 1994). These interactions can produce a marked dominance of a few species, especially invasive ones (Hanski, 1987; Wells \& Greenberg, 1994). According to Schoenly \& Reid (1987), the hypothesis of a discrete process would imply a higher similarity in species composition within a given stage of decomposition than between stages. However, this was not observed in this study, given the enormous overlap in the species throughout the decomposition, and this pattern is consistent in both seasons as detected by the Cluster analysis (Figs. 3A, B).

Twelve species reported here have been documented as colonizers of human cadavers: C. albiceps, C. megacephala, Chrysomya putoria Wiedemann, 1819, C. macellaria, $H$. semidiaphana, Hemilucilia segmentaria Fabricius, 1805, (Calliphoridae), O. riograndensis (Sarcophagidae), Musca domestica Linnaeus, 1758 and O. chalcogaster (Muscidae), Megaselia scalaris Loew, 1866 (Phoridae), Piophila casei Linnaeus, 1758 (Piophilidae) and $H$. illucens (Stratiomyidae). This reinforces the importance of forensic relevance of this study since peri-urban fragments of forest are amongst the most frequently used sites for discarding cadavers of victims of homicide.

Species from the genus Chrysomya, dominant in this study, are the most frequently used species in the estimation of minimum PMI worldwide (Byrd \& Castner, 2010), but information on the presence and age of the native species $H$. segmentaria helped to estimate the PMI in a criminal case in Brazil (Kosmann et al., 2011). In a study performed in Recife, larvae of $H$. segmentaria were recovered from the soil below a cadaver victim of suicide by hanging, which further stimulates investigation on this species' forensic relevance (Vasconcelos et al., 2019).

Although complete identification was not achieved for all Sarcophagidae, the record of at least 10 species reported here reinforces the diversity of the family in Neotropical environments, especially of the genus Oxysarcodexia and Peckia. The relatively limited forensic application (e.g., PMI) of Muscidae so far may be due to difficulties in rearing and identification, as well as due to their preference for other substrates, such as decomposing plant material. In a recent review, Grzywacz et al. (2017) highlight that although fewer muscids are known to colonize human cadavers than species of Calliphoridae, corpses may be colonized out- or indoors, in sunny or shaded, dry or wet sites, in exposed or concealed situations, and at early and late stages of decomposition. We found five species in association with pig carcasses, and the dominance of $O$. chalcogaster raises questions whether the forensic potential of muscids has been underestimated (Grzywacz et al., 2017).

Field surveys of necrophagous dipterans can also strengthen their potential as biological indicators of environmental conservation or indicators of the site of death. For example, the presence of Mesembrinella bellardiana (Aldrich, 1922) and Hemilucilia species reflects an intimate association with forested areas, as they are rare or absent in urban zones (Cabrini et al., 2013; Carmo \& Vasconcelos, 2016; Thyssen et al., 2005).

Given the experiments' short duration, our results present a conservative estimate of the actual diversity of necrophagous Diptera in rainforest fragments in Northeastern Brazil. Nevertheless, our data contribute to expand the knowledge on the geographical distribution of forensically relevant species and confirm the rapid dissemination of invasive Chrysomya species in forested areas. Further studies should investigate the life cycle of native species and how they respond to environmental differences so that criminal investigators can effectively use entomology databases.

\section{ACKNOWLEDGEMENTS}

We thank the management of Dois Irmãos State Park for the permission to perform this experiment, Dr. Fred Maranhão and Dr. Sandra Santos (Instituto de Criminalística Professor Armando Samico), Roberta Salgado, Ana Mayer and Thiago Oliveira (UFPE) for logistical support, Coordenação de Aperfeiçoamento de Pessoal de Nível Superior (CAPES), Conselho Nacional de Desenvolvimento Científico e Tecnológico (CNPq), and Fundação de Amparo à Ciência e Tecnologia do Estado de Pernambuco (FACEPE) for financial help. All samplings were performed with the authorization of the Instituto Chico Mendes de Conservação da Biodiversidade (ICMBio).

\section{AUTHORS' CONTRIBUTIONS}

Conceived and designed the project: TMC, SDV. Collected field samples: TMC, SDV. Analyzed the data: TMB, TMC, SDV. Species identification: TMC, PJT. Wrote the paper: TMB, TMC, PJT, SDV. All authors read and approved the final version of the manuscript.

\section{REFERENCES}

Andrade, H.T.A.; Varela-Freire, A.A.; Batista, M.J.A. \& Medeiros, J.F. 2005. Calliphoridae (Diptera) coletados em cadáveres humanos no Rio Grande do Norte. Neotropical Entomology, 24: 855-856. http://www.scielo.br/ pdf/ne/v34n5/a21v34n5.pdf.

Arnaldos, I.; Romera, E.; Garcia, M.D. \& Luna, A. 2001. An initial study on the succession of sarcosaprophagous Diptera (Insecta) on carrion in the southeastern Iberian Peninsula. International Journal of Legal Medicine, 114: 156-162.

Barbosa, R.R.; Mello-Patiu, C.A.; Ururahy-Rodrigues, A.; Barbosa, C.G. \& Queiroz, M.M.C. 2010. Temporal distribution of ten calyptrate dipteran species of medicolegal importance in Rio de Janeiro, Brazil. Memórias do Instituto Oswaldo Cruz, 105(2): 191-198.

Barbosa, T.M.; Carmo, R.F.R.; Silva, L.P.; Sales, R.G. \& Vasconcelos, S.D. 2017. Diversity of sarcosaprophagous calyptratae (Diptera) on sandy beaches exposed to increasing levels of urbanization in Brazil. Environmental Entomology, 46(3): 460-469. 
Byrd, J.H. \& Castner, J.L. 2010. Forensic entomology: the utility of Arthropods in legal investigations. 2.ed. Boca Raton, CRC Press. 681p.

Cabrini, I.; Grella, M.D. \& Thyssen, P.J. 2013. Richness and composition of Calliphoridae in an Atlantic Forest fragment: implication for the use of dipteran species as bioindicators. Biodiversity and Conservation, 22(11): 2635-2643.

Carmo, R.F.R. \& Vasconcelos, S.D. 2016. Assemblage of necrophagous Diptera in atlantic insular environments and response to different levels of human presence. Neotropical Entomology, 45: 471-481.

Carvalho, C.J.B. \& Mello-Patiu, C.A. 2008. Key to the adults of the most common forensic species of Diptera in South America. Revista Brasileira de Entomologia, 52: 390-406. http://www.scielo.br/pdf/rbent/v52n3/ a12v52n3.pdf.

Carvalho, C.J.B.; Moura, M.O. \& Ribeiro, P.B. 2002. Chave para adultos de dípteros (Muscidae, Fanniidae, Anthomyiidae) associados ao ambiente humano no Brasil. Revista Brasileira de Entomologia, 46: 107-114. http:// www.scielo.br/pdf/rbent/v46n2/a01v46n2.pdf.

Carvalho, C.J.B.; Rafael, J.A.; Couri, M.S. \& Silva, V.C. 2012. Diptera. In: Rafael, J.A.; Melo, G.A.R.; Carvalho, C.J.B.; Casari, S.A. \& Constantino R. (Eds.). Insetos do Brasil, diversidade e taxonomia. Ribeirão Preto, Ed. Fapeam/ Holos. 810p.

Carvalho, L.M.L. \& Linhares, A.X. 2001. Seasonality of insect succession and pig carcass decomposition in a natural forest area in Southeastern Brazil. Journal of Forensic Science, 46: 604-608.

Disney, R.H.L. \& Aguiar, A.M.F. 2008. Scuttle flies (Diptera: Phoridae) of Madeira. Fragmenta Faunistica, 51: 23-62.

Faria, L.D.B.; Orsi, L.; Trinca, L.A. \& Godoy, W.A.C. 1999. Larval predation by Chrysomya albiceps on Cochliomyia macellaria, Chrysomya megacephala and Chrysomya putoria. Entomologia Experimentalis et Applicata, 90: 149-155.

Ferrari, A.C.; Soares, A.T.C.; Amorim, D.S.; Thyssen, P.J. \& Guimarães, M.A. 2009. Comparação dos padrões de atratividade de Hermetia illucens (Diptera, Stratiomyidae) associada a carcaças de Rattus norvergicus enterradas e tratadas com hormônios esteroides. Revista Brasileira de Entomologia, 53: 565-569. http://www.scielo.br/pdf/rbent/v53n4/06.pdf.

Grzywacz, A.; Hall, M.J.R.; Pape, T. \& Szpila, K. 2017. Muscidae (Diptera) of forensic importance an identification key to third instar larvae of the western Palaearctic region and a catalogue of the muscid carrion community. International Journal of Legal Medicine, 131: 855-866.

Hanski, I. 1987. Carrion fly community dynamics: patchiness, seasonality and coexistence. Ecological Entomology, 12: 257-266.

Horenstein, M.B.; Rosso, B. \& García, M.D. 2012. Seasonal structure and dynamics of sarcosaprophagous fauna on pig carrion in a rural area of Cordoba (Argentina): Their importance in forensic Science. Forensic Science International, 217: 146-156.

Kosmann, C.; Macedo, M.P.; Barbosa, T.A.F. \& Pujol-Luz, J.R. 2011. Chrysomya albiceps (Wiedemann) and Hemilucilia segmentaria (Fabricius) (Diptera, (alliphoridae) used to estimate the postmortem interval in a forensic case in Minas Gerais, Brazil. Revista Brasileira de Entomologia, 55: 621-623. http://www.scielo.br/pdf/rbent/v55n4/v55n4a22.pdf.

Krüger, R.F.; Ribeiro, P.B.; Carvalho, C.J.B.; Lambrecht, F.M. \& Nunes, A.M. 2004. Longevidade e oviposição de Ophyra albuquerquei (Diptera, Muscidae) em condições de laboratório. Iheringia, Série Zoologia, 94: 211-216. http:// www.scielo.br/pdf/isz/v94n2/21595.pdf.

Machado, I.C.; Lopes, A.V. \& Porto, K.C. 1998. Reserva Ecológica de Dois Irmãos: estudos em um remanescente de Mata Atlântica em área urbana (Recife, Pernambuco, Brasil). Recife, Editora Universitária. 326p.

Mc Alpine, J.F.; Peterson, B.V.; Shewell, G.E.; Teskey, H.J.; Vockeroth, J.R. \& Wood, D.M. 1981. Manual of Nearctic Diptera. Vol. 1. Ottawa, Research Branch Agriculture Canada. 674p.
Mexico, 2017. Metodología del ranking (2016) de las 50 ciudades más violentas del mundo. Consejo Ciudadano para la Seguridad Pública y Justicia Penal. Available: http://www.seguridadjusticiaypaz.org.mx/biblioteca/prensa/ send/6-prensa/239-las-50-ciudades-mas-violentas-del-mundo-2016metodologia. Access: 12/06/2017.

Moura, M.0.; Monteiro-Filho, E.L.A. \& Carvalho, C.J.B. 2005. Heterotrophic succession in carrion arthropod assemblages. Brazilian Archives of Biology and Technology, 48: 477-486. http://www.scielo.br/pdf/babt/v48n3/24770.pdf.

Oliveira, T.C. \& Vasconcelos, S.D. 2010. Insects (Diptera) associated with cadavers at the Institute of Legal Medicine in Pernambuco, Brazil and its implications for forensic entomology. Forensic Science International, 198: 97-102.

Pamplona, D. \& Couri, M.S. 1989. Revisão das espécies neotropicais de Ophyra Robineau-Desvoidy, 1830 (Diptera, Muscidae, Azeliinae). Memórias do Instituto Oswaldo Cruz, 84(Supl. IV): 419-429.

Payne, J.A. 1965. A summer carrion study of the baby Pig Sus scrofa Linnaeus. Ecology, 46: 592-602.

Rochefort, S.; Giroux, M.; Savage, J. \& Wheeler, T.A. 2015. Key to forensically important Piophilidae (Diptera) in the Neartic Region. Canadian Journal of Arthropod Identification, 27: 1-37. https://biotaxa.org/cjai/article/ view/13308.

Rodriguez, W.C. \& Bass, W.M. 1983. Insect activity and its relationship to decay rates of human cadavers in East Tennessee. Journal of Forensic Science, 28: 423-432.

Schoenly, K. \& Reid, W. 1987. Dynamics of heterotrophic succession in carrion arthropod assemblages: discrete series or a continuum of change. Oecologia, 73: 192-202.

Skidmore, P. 1985. The biology of the Muscidae of World. Dordrecht, Junk Publishers. 550p.

Souza, A.M. \& Linhares, A.X. 1997. Diptera and Coleoptera of potential forensic importance in southeastern Brazil: relative abundance and seasonality. Medical and Veterinary Entomology, 11: 8-12.

Tachibana, S.I. \& Numata, H. 2006. Seasonal prevalence of blowflies and flesh flies in Osaka City. Entomological Science, 9: 341-145.

Thyssen, P.J.; Lessinger, A.C.; Azeredo-Espin, A.M.L. \& Linhares, A.X. 2005. The value of PCR-RFLP molecular markers for the differentiation of immature stages of two necrophagous flies (Diptera: Calliphoridae) of potential forensic importance. Neotropical Entomology, 34: 777-783. http://www. scielo.br/pdf/ne/v34n5/a09v34n5.pdf.

Tomberlin, J.K.; Byrd, J.H.; Wallace, J.R. \& Benbow, M.E. 2012. Assessment of decomposition studies indicates need for Standardized and Repeatable Research Methods in Forensic Entomology. Journal of Forensic Research, 3: 147.

Vasconcelos, S.D.; Costa, D.L. \& Oliveira, D.L. 2019. Entomological evidence in a case of a suicide victim by hanging: first collaboration between entomologist and forensic police in northeastern Brazil. Australian Journal of Forensic Science, 51: 231-139.

Vasconcelos, S.D.; Cruz, T.M.; Salgado, R.L. \& Thyssen, P.J. 2013. Dipterans associated with a decomposing animal carcass in a rainforest fragment in Brazil: Notes on the early arrival and colonization by necrophagous species. Journal of Insect Science, 13: 1-11.

Vasconcelos, S.D.; Soares, T.F. \& Costa, D.L. 2014. Multiple colonization of a cadaver by insects in an indoor environment: First record of Fannia trimaculata (Diptera: Fanniidae) and Peckia (Peckia) chrysostoma (Sarcophagidae) as colonizers of a human corpse. International Journal of Legal Medicine, 11: 1-5.

Waiselfisz, J.J. 2016. Mapa da Violência 2016. Available: http://www. mapadaviolencia.org.br/pdf2016/Mapa2016 armas web.pdf. Access: 10/06/2017.

Wells, J.D. \& Greenberg, B. 1994. Resource use by introduced and native carrion flies. Oecologia, 3: 601-608. 